\title{
Formulation of Coated Tablets Film Of Jengkol Fruit Seeds (Pithecellobium lobatum Benth.) as A Selenium Herbal Supplement
}

\author{
Dolih Gozali $^{1 *}$, Mutakin ${ }^{2}$, Yunita ${ }^{1}$, Norisca Aliza1 \\ ${ }^{1}$ Department of Pharmaceutics and Pharmaceutical Technology, Faculty of Pharmacy, Universitas \\ Padjadjaran, Bandung, Indonesia \\ ${ }^{2}$ Department of Pharmaceutical Analysis and Medicinal Chemistry, Faculty of Pharmacy, Universitas \\ Padjadjaran, Bandung, Indonesia
}

Received : 01 Aug 2020, Revised : 11 Sept 2020, Accepted : 08 Oct 2020, Published : 21 Oct 2020

\begin{abstract}
The correlation between the high content of selenium (Se) in plasma and the low prevalence of cardiovascular disease has been published in previous epidemiological studies. The content of Se in the plasma is determined by daily intake. A preliminary surveillance of Se content of several plants showed that the seeds of jengkol (Pithecellobium lobatum Benth.) has the highest concentration of Se. This study aims to develop a pharmaceutical formulation of Se supplement for adjuvant therapy of cardiovascular disease. The jengkol seeds was made into film coated tablets with a wet granulation method. Optimization of the core tablet formula was carried out with variations of binder concentration and coating material. Evaluation was carried out on uniformity of size and weight, disintegration time, hardness and friability. The content evaluation was carried out including the levels of Se, water content, ash, fat, protein, carbohydrate and crude fiber. The results showed that the F3 had the lowest friability and highest hardness. The coating of tablets using PVA has covered the smell of jengkol seed. The evaluation results showed that film coated tablets contained the Se level content of $0.074 \pm 0.004 \mu \mathrm{g} / \mathrm{g}$, water content of $2.19 \%$, ash content of $1.88 \%$, fat content of $0.89 \%$, protein content of $0.66 \%$, carbohydrate content of $94.38 \%$ and crude fiber content $1.79 \%$. The results showed that the jengkol seed film coated tablet formulation could be used as a supplement in additional therapy for cardiovascular disease.
\end{abstract}

Keywords : Pithecellobium lobatum, film coated tablet, herbal supplement, selenium

\section{BACKGROUND}

The jengkol plant is a typical plant that grows in Southeast Asia, including in Indonesia. This plant includes plants that are commonly eaten (edible plant). The used and consumed part of this plant is the seeds. Jengkol fruit seeds are commonly consumed by Indonesians, including those in West Java. The nutritional content contained in jengkol fruit seeds includes vitamin C, jencolic acid, tannins, flavonoids and saponins (1). Jengkol fruit seeds have a distinctive and pungent odor due to the presence of the amino acid cysteine which contains sulfur
(2). Some plants contain Selenium (Se), one of which is the jengkol plant. It is necessary to first determine the Se content in the seeds of jengkol fruit to determine the range of Se content in the seeds of jengkol fruit because so far there has been no research that has conducted the determination of the Se content in the seeds of the jengkol fruit.

Se is a micronutrient needed by the body. The organic and inorganic forms of Se serve as a source of the mineral Se for the body. Se intake can be obtained from food, drinks or in the form 
of Se supplements (3). Foods that have been known to contain Se include meat, seafood, dairy products, onions and others $(3.4$. The Se content in plants is strongly influenced by the Se content in the soil, so that there can be differences in the content in plants depending on the area where it is grown (5).

The recommended amount of selenium intake per day is $55 \mu \mathrm{g} /$ day and the maximum tolerance limit is $400 \mu \mathrm{g} / \mathrm{day}$. The amount of the need for each individual depends on sex, age, pregnancy and geographic area (6). If in deficiency conditions it can cause Keshan disease, Kashin-Beck disease, thyroid disorders, cancer, cardiovascular disease, and reproductive problems. Meanwhile, if it exceeds the maximum limit it can cause toxicity (7). There has been research that proves that there is an inverse correlation between the prevalence of cardiovascular disease with the Se concentration in rice consumed and the nutritional status of $\mathrm{Se}$, where the areas with the highest $\mathrm{Se}$ concentrations have the lowest prevalence of cardiovascular disease, stroke and hypertension (8). In addition, in Indonesia the prevalence of cardiovascular disease and stroke is very high, namely $12.1 \%$ (9). According to WHO, cardiovascular disease is the number one cause of death in the world (10). So that Se has an important role for human health and to overcome differences in Se intake in areas with low levels of Se in soil, Se supplementation can be one of the supportive therapeutic solutions. Because a good supplement is a supplement with food, food sources that are rich in Se are used as raw material for supplements, namely jengkol fruit seeds.

The unpleasant smell of the jengkol fruit seeds causes some people to dislike consuming them. So that from this background, it is necessary to formulate the film-coated tablet dosage form of jengkol fruit seeds to cover the odor of tablets and increase consumption interest. Tablets were prepared using the wet granulation method and with a PVA coating solution.

\section{METHODS}

Jengkol seed preparation. Jengkol fruit seeds were collected from 15 districts / cities in West Java which had been determined by random sampling method. Jengkol seeds were mashed in a blender and weighed as much as $400 \mathrm{mg}$ to digest with $2 \mathrm{ml}$ of nitric acid: perchloric acid (2: 1) for 8 hours. Then $0.5 \mathrm{ml}$ of $10 \mathrm{~N} \mathrm{HCl}$ solution was added and heated again for 20 minutes at a temperature of $150^{\circ} \mathrm{C}$ and then cooled.

\section{Formulation of Jengkol Seed Core Tablets.}

The inner phase consists of jengkol seed powder, lactose, 5\% amprotab, and $12.5 \%$ starch paste. Starch paste solution is added gradually to the mixture of jengkol seed powder, lactose, and ampoule until a mass is formed.

which can be clenched, then sieved using mesh number 16. Drying is perfomed by using an oven at a temperature of $40-50^{\circ} \mathrm{C}$ for 18 hours. The outer phase $(5 \%$ ampoule, talc and magnesium) is added to the dry granule. The print mass was evaluated by LOD testing, bulk density, compressible tap density, compressibility, flow rate and angle of rest. The printed mass is then printed using punch number 13 with a maximum weight of $650 \mathrm{mg}$ per tablet.

Table 1. Jengkol seed core tablet formula

\begin{tabular}{llll}
\hline \multirow{2}{*}{ Ingredient } & \multicolumn{3}{l}{ Formula $(\% \mathrm{~b} / \mathrm{b})$} \\
\cline { 2 - 4 } & 1 & 2 & 3 \\
\hline Jengkol Fruit Seeds & 20 & 20 & 20 \\
Amprotab & 10 & 10 & 10 \\
Starch Paste & 2 & 3 & 5 \\
Lactose & 65 & 64 & 62 \\
Talc & 2 & 2 & 2 \\
Mg Stearate & 1 & 1 & 1 \\
\hline
\end{tabular}

Coating tablets. Coating solutions are prepared by dissolving the ingredients in Table 2 in 900 grams of water at a temperature of $90^{\circ} \mathrm{C}-95^{\circ} \mathrm{C}$. Then the coating is done using the pan coating method. 
Table 2. Coating Solution Formula

\begin{tabular}{ll}
\hline Ingredient & $\begin{array}{l}\text { Formula } \\
(\%)\end{array}$ \\
\hline Polyvinyl alcohol & 40 \\
Propylenglycol & 10 \\
Glyceryl & 20 \\
Monostearate & \\
$\mathrm{TiO}_{2}$ & 20 \\
Apple Green L.T & 10 \\
\hline
\end{tabular}

The evaluation of core tablets and coated tablets included organoleptic test, diameter, thickness and uniformity of weight, hardness, friability, and tablet disintegration test. In the coated tablet, additional evaluation was carried out, namely the percent increase in weight, determination of Se content and proximate analysis and crude fiber content.

\section{Determination of Se content in the preparation.}

20 tablets were crushed and weighed as much as $400 \mathrm{mg}$ because the sample had low Se content (vegetables) (11) to be digested with $4 \mathrm{ml}$ of nitric acid: perchloric acid (2: 1) for 8 hours. Then $0.5 \mathrm{ml}$ of $10 \mathrm{~N} \mathrm{HCl}$ solution was added to reduce selenate $\left(\mathrm{SeO}_{42^{-}}\right)$to selenite $\left(\mathrm{SeO}_{32-}\right)$ and heated again for 20 minutes at $150 \mathrm{C}^{0}$ and then cooled. After that, $0.1 \mathrm{ml}$ of $0.1 \mathrm{ml}$ EDTA solution was added as a chelating agent that would bind other metals which could interfere with the measurement (12); $20 \mu \mathrm{l}$ of $1 \%$ thymol blue solution until the solution turns red. $25 \%$ $\mathrm{NH} 4 \mathrm{OH}$ was added (in the water bath) until the color turned blue and $2 \mathrm{~N} \mathrm{HCl}$ was dropped until the solution turned pink. $1 \mathrm{ml}$ of $0.1 \mathrm{~N} \mathrm{HCl}, 1$ $\mathrm{ml}$ of 2.3 -DAN $0.1 \%$ solution at $50^{\circ} \mathrm{C}$ while shaking for 10 minutes. The formation of selenium complexes with 2.3diaminonaphthalene $0.1 \%$ (AND $0.1 \%$ ) forms 4.5-benzopiazselenol compounds or can be referred to as nafto-2-selena-1.3-diazole 12). When finished, the tubes were cooled to room temperature (to allow the $\mathrm{Se} 3+$ and 2.3-DAN reactions to occur). After cooling, $2 \mathrm{ml}$ of cyclohexane were added, covered, shaken for 2 minutes and centrifuged for 5 minutes at a speed of $2500 \mathrm{rpm}$. The cyclohexane part was taken as much as $100 \mu \mathrm{l}$ and put into the microplate well-96 and the intensity was measured with excitation $378 \mathrm{~nm}$ and emission of $525 \mathrm{~nm}$ on a fluorometer.

\section{Proximate analysis and crude fiber content in film coated tablets.}

Proximate and crude fiber analysis was carried out at the Test Laboratory of the Faculty of Agricultural Industrial Technology, UNPAD. Analysis of the fat content of the Soxhlet method, the protein content of the Kjeldahl method, the water content of the gravimetric method and the ash content were carried out by the test methods listed in SNI 01: 2891: 1992. The analysis of carbohydrates was carried out using the method by difference, namely by reducing $100 \%$ the moisture content, ash content, protein content, and fat content. While the analysis of crude fiber content was carried out by the hydrolysis testing method.

\section{RESULTS AND DISCUSSION}

The jengkol fruit seeds tested came from 15 different regions in West Java. Measurement of Se content in jengkol fruit seeds was carried out using the Watkinson method. This method measures the selenium content in the acid digested sample using a fluorometer.

From the measurement results, the highest Se content was found in jengkol fruit seeds from Subang Regency (Sagalaherang Market), namely $0.4980 \pm 0.0666 \mu \mathrm{g} / \mathrm{g}$. Differences in Se content in jengkol fruit seeds from different areas may occur due to differences in Se content in the soil where the jengkol grows. So far there has been no research on the analysis of $\mathrm{Se}$ content in jengkol fruit seeds, so there is no comparable range of Se levels. However, when compared with other vegetables such as garlic [0.021 $\mu \mathrm{g} / \mathrm{g}$ (13)]; cabbage [0.002-0.014 $\mu \mathrm{g} / \mathrm{g}$ (14)]; petai $(0.0242-0.2579 \mu \mathrm{g} / \mathrm{g})$ and spinach 
$[0.024 \mu \mathrm{g} / \mathrm{g}(15)]$, the Se content in the seeds of jengkol fruit is very high. So that it can be used as a raw material for making herbal supplements Se.

The wet granulation method was chosen because the jengkol used was still a wet material so that this method could simultaneously reduce the water content in the jengkol and also to obtain a good flow rate. The binder used was starch paste $12.5 \%$ with a concentration variation of 2\% (F1); 3\% (F2) and 5\% (F3). The concentration of starch paste commonly used as a tablet binder is $3-20 \%$ (16). In order to determine the best binder concentration, evaluation was carried out on the resulting print and tablet mass.

Table 3. Results of Mass Evaluation of Tablet

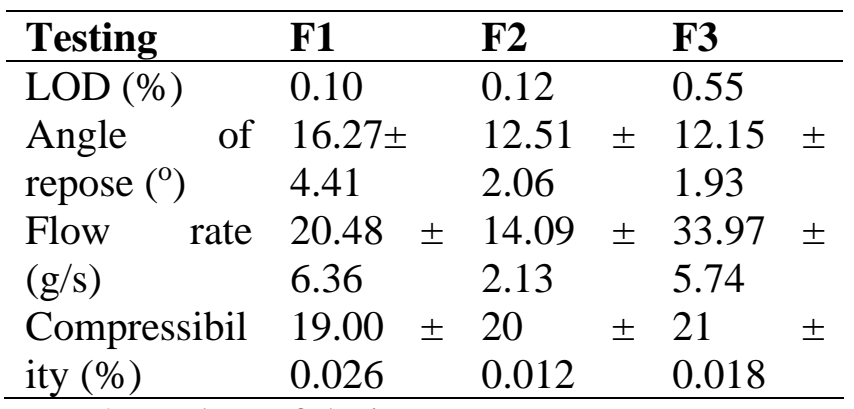

$$
\text { LOD }=\text { lost of drying }
$$

The LOD value from the print mass evaluation results shows the water content contained in the print mass. The requirement for the LOD value is $<1-2 \%$. The result is that F3 has the highest LOD value, namely $0.55 \%$.

The results of the evaluation of the angle of rest for the three formulas are less than 25o, which means that the three formulas have very good angles of rest. However, F3 has the best angle of rest and has the best flow rate of $33.97 \mathrm{~g} / \mathrm{s}$. The flow rate and angle of rest of the print mass will affect the ability of the granules to flow through the hopper during the printing process and affect the uniform weight of the tablets.

The ease of the print mass to be compressed into a tablet can be seen from the compressibility value. The compressibility value of the three formulas falls into the moderate category, namely $18-22 \%$. But F1 has the lowest compressibility among all formulas.

Table 4. Tablet Evaluation Results

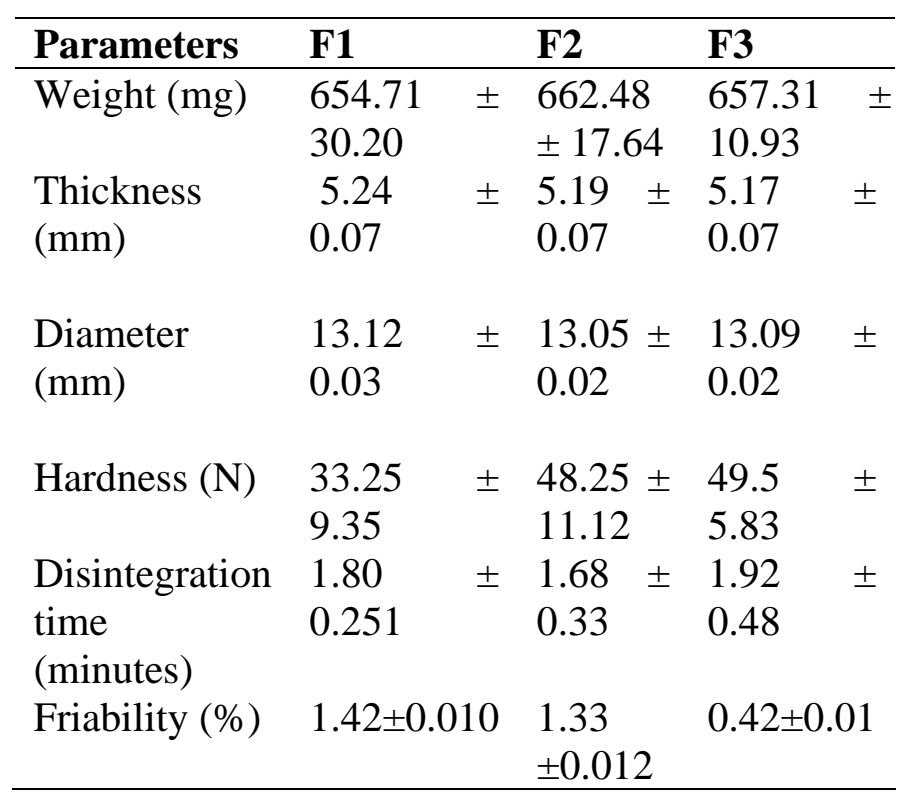

After all granular mass were compressed by tableting process then its quality were evaluated. The core tablets produced from F1, F2 and F3 have a round biconvex shape, are white in color with brownish spots and smell of jengkol which can be seen in appendix 3. This shape is in accordance with the ideal core tablet shape for coating, namely elliptical, round bikonvek or oval bikonvex. and spherical (17).

The results of the $\mathrm{F} 1, \mathrm{~F} 2$ and $\mathrm{F} 3$ weight uniformity tests in Appendix 4 meet the requirements because no two tablets deviate by $5 \%$ and none of the tablets deviates by $10 \%$ from the average weight of the tablets. Likewise, from the results of the size uniformity test, tablets from F1, F2 and F3 meet the requirements because they have a diameter not more than 3 times and not less than $4 / 3$ the thickness of the tablet (9). In the hardness test, tablets with F1 had the lowest hardness and did not meet the requirements because they were less than $40 \mathrm{~N}$. Whereas tablets with F2 and F3 
met the hardness requirements because they were between $40-80 \mathrm{~N}$. The hardness of the tablets could be affected by the amount of punch pressure in the tableting process.

The result of the disintegration time test showed that all formulas meet the requirements because the tablet disintegration time is less than 15 minutes. The duration of disintegration is influenced by the concentration of the binder and is directly proportional to the hardness of the tablet. Tablets with higher hardness will have longer disintegration times. Because the coating process will be carried out on the tablet, the friability test is very important to do. The result of the three formulas, only F3 meets the friability requirements because $<1 \%$ is equal to $0.412 \%$.

Through the binder optimization process, the results showed that $\mathrm{F} 3$ with a starch paste binder concentration of $5 \%$ produced tablets with the highest hardness and lowest friability. So then the production of core tablets was made by using F3. Production of tablets was made in 3 batches with 250 tablets each. During the production process, evaluation of the mass of compressed tablet and evaluation of core tablets were also carried out.

The results of the LOD test on the tablet print mass met the requirements and the results were close to the LOD value of the F3 formula at the optimization stage. The resulting print mass has a flow rate and an angle of rest that fall into the very good category. But it has enough compressibility because it is between $18-22 \%$.

After the mass evaluation process is carried out, then the print mass is compressed using punch 13 to produce the core tablet. The resulting core tablet has a round biconvex shape, is white with brownish spots and smells of jengkol.

Furthermore, the evaluation of tablets includes weight uniformity, size uniformity, hardness, disintegration time and friability.
Based on the results of the weight uniformity test (data not shown), the tablets meet the weight uniformity requirements because no two tablets deviated by $5 \%$ and none of the tablets deviated by $10 \%$ from the average weight of the tablets. Likewise, from the results of the size uniformity test, tablets meet the requirements because they have a diameter of no more than 3 times and or not less than $4 / 3$ the thickness of the tablet (9). The value of tablet hardness at the production stage is not much different from the optimization stage, but is smaller than the optimization stage. The difference in hardness can occur due to the different amount of punch pressure during the printing process. But the hardness of the tablet meets the requirements because it is between $40-80 \mathrm{~N}$, which is $45.95 \pm$ $2.47 \mathrm{~N}$.

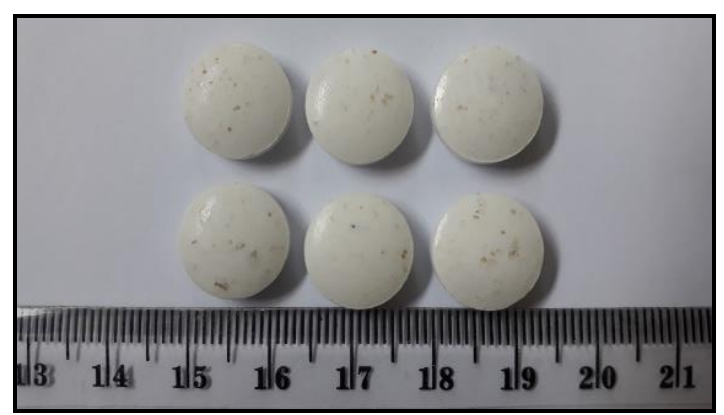

Figure 1. Physical Appearance of Jengkol Fruit Seed Core Tablets

The tablet disintegration time met the requirements because of the six tablets used in the disintegration test all of them disintegrated in less than 15 minutes for an ordinary, uncoated tablet. The disintegration time can be affected in part by the hardness of the tablet. Because tablets at this production stage have less hardness, they will have a faster disintegration time than the same formula in the optimization stage. Another important evaluation for the tablet to be coated is friability. The hardness or friability of tablets is related to the hardness of tablets, because generally tablets with high hardness have low friction. If the friability of the core tablet is too high then the released fine particles will stick 
with the coating droplets on the tablet surface during the coating process which will cause the coating layer formed to become rough and uneven. The result is that the tablet friability meets the requirements because it is less than $1 \%$. Furthermore, the coating process is carried out on the core tablet with the printed F3 formula.

Table 5. Results of Mass Evaluation of Tablet Print in the Production Stage

\begin{tabular}{ll}
\hline Testing & Result \\
\hline $\begin{array}{l}\text { LOD }(\%) \\
\text { Angle of Repose }\end{array}$ & $0.41 \pm 0.26$ \\
$\left({ }^{\circ}\right)$ & \\
Low rate $(\mathrm{g} / \mathrm{s})$ & $101.85 \pm 13.49$ \\
$\begin{array}{l}\text { Compressibility } \\
(\%)\end{array}$ & $19 \pm 0.017$ \\
\hline
\end{tabular}

The purpose of tablet coating in this formulation is to mask the unpleasant odor of the tablet preparation. The polymer used as a coating is polyvinyl alcohol. The use of propylenglycol and glyceryl monostearate in coating solutions functions as a plasticizer and emulsifying agent. The plasticizer functions to prevent the film from becoming brittle and minimize defects in the coating layer (18), while the emulsifying agent functions so that the coating solution can mix homogeneously and stick to the tablet surface. In the coating solution formula, titanium oxide and apple green coloring are also added to make the preparation more attractive.

The physical appearance of the film coated tablets is round bikonvex, green in color with a less pungent jengkol odor. Coating is carried out until the increase in tablet weight is in the $2-5 \%$ range. The result is an increase in tablet weight of $2.6 \%$ fulfills the requirements because it is in the $2-5 \%$ range (19). But not enough to cover up the smell of the tablet. So that a further coating process can be carried out, because the thicker the coating layer, the more it will cover the smell of the tablet.
Table 6. Evaluation Results of Core Tablets in the Production Stage

\begin{tabular}{ll}
\hline Parameters & Results \\
\hline Weight $(\mathrm{mg})$ & $643.8 \pm 5.9$ \\
Thickness $(\mathrm{mm})$ & $5.07 \pm 0.036$ \\
Diameter $(\mathrm{mm})$ & $13.09 \pm 0.039$ \\
Hardness $(\mathrm{N})$ & $45.95 \pm 2.474$ \\
Disintegration & $1.51 \pm 0.087$ \\
time (minutes) & \\
Friability (\%) & $0.724 \pm 0.011$ \\
\hline
\end{tabular}

Table 7. Physical Evaluation Results of Film Coated Tablets

\begin{tabular}{ll}
\hline Parameters & Results \\
\hline $\begin{array}{l}\text { Weight }(\mathrm{mg}) \\
\text { Thickness } \\
(\mathrm{mm})\end{array}$ & $663.4 \pm 11.5$ \\
$\begin{array}{l}\text { Diameter } \\
(\mathrm{mm})\end{array}$ & $13.19 \pm 0.038$ \\
Hardness (N) & $46.183 \pm 1.765$ \\
$\begin{array}{l}\text { Disintegration } \\
\text { time } \\
\text { (minutes) }\end{array}$ & $3.46 \pm 0.413$ \\
$\begin{array}{l}\text { Friability (\%) } \\
\text { Increase in } \\
\text { weight }(\%)\end{array}$ & $0.088 \pm 0.0003$ \\
\hline
\end{tabular}

Table 8. Evaluation Results of Chemical Content of Film Coated Tablets

\begin{tabular}{ll}
\hline Parameters & Results \\
\hline Se content $(\mu \mathrm{g} /$ & $0.074 \pm 0.004$ \\
$\mathrm{~g}$ tab) & \\
Water $(\%)$ & $2.19 \pm 0.003$ \\
Ash $(\%)$ & $1.88 \pm 0.005$ \\
Protein $(\%)$ & $0.66 \pm 0.002$ \\
Fat $(\%)$ & $0.89 \pm 0.001$ \\
Carbohydrate & $94.38 \pm 0.012$ \\
$(\%)$ & \\
Crude fiber $(\%)$ & $1.79 \pm 0.003$ \\
\hline
\end{tabular}

The coated tablet has a greater average weight than the core tablet. Theoretically the final coated tablet would weigh $660.5 \mathrm{mg}$. Based on the results of the weight uniformity test (data not shown), the tablets met the requirements 
because there were no two tablets whose weight deviated by $5 \%$ and not a single tablet had $10 \%$ deviating weight from the average weight of the tablets.

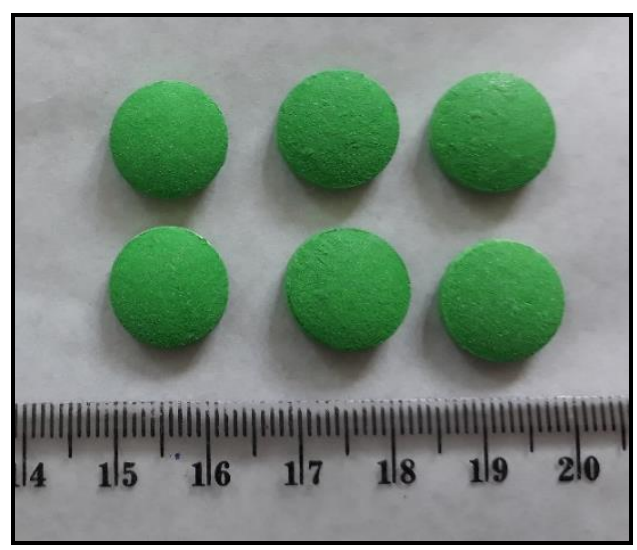

Figure 2. Physical Appearance of Jengkol Fruit Seed Film Coated Tablets

The coating process also causes an increase in the diameter, thickness, hardness and crush time of the tablets. However, the size of the tablet still meets the requirements because it has a diameter that is not more than 3 times (16.2 $\mathrm{mm}$ ) or not less than $4 / 3$ the thickness of the tablet $(7.2 \mathrm{~mm})$. The hardness of the film coated tablet still meets the requirements because it is in the range of 40-80 N. The increase in tablet hardness occurs because wat

er from the coating solution that enters the tablet will increase the compactness of the tablet so that the tablet becomes harder. Film coated tablets have a longer disintegration time than core tablets because of the polymer coating the tablet surface so it takes longer time for the tablets to dissolve. In the coating process, the pores on the tablet surface are covered by a coating solution so that it will slow down the penetration of the liquid when crushed (20). The yield of the disintegration time of film coated tablets was 3.46

\section{CONCLUSION}

Based on the evaluation of compressed mass and tablet quality at the optimization stage, the
F3 formula has the lowest tablet friability value and the highest tablet hardness. The formula for the film coated tablet of jengkol fruit seeds (Pithecellobium lobatum Benth.) used the F3 formula (5\% starch paste binder) with the coating solution used is PVA to cover odors. The results of the physical evaluation of the jengkol seed film coated tablets met the pharmacopoeial requirements and the film coated tablets contained Se of $0.074 \pm 0.004$ $\mu \mathrm{g} / \mathrm{g}$; water content of $2.19 \%$; ash content of $1.88 \%$; fat content of $0.89 \%$; protein content of $0.66 \%$; carbohydrate content of $94.38 \%$ and crude fiber content of $1.79 \%$ but coating the tablets using PVA could not cover the smell of the initial raw material.

\section{REFERENCES}

1. Hutapea Ria Johnny. Inventaris Tanaman Obat Indonesia Jilid III. Dep Kesehat RI Badan Penelit dan Pengemb Kesehat. 1994;

2. Pebriana RB. Cosmos Caudatus Kunth: A Traditional Medicinal Herb. Glob J Pharmacol. 2014;

3. Ross AC, Caballero B, Cousins RJ, Tucker KL, Ziegler TR. Modern nutrition in health and disease: Eleventh edition. Modern Nutrition in Health and Disease: Eleventh Edition. 2012.

4. Erdman JW, MacDonald IA, Zeisel SH. Present Knowledge in Nutrition: Tenth Edition. Present Knowledge in Nutrition: Tenth Edition. 2012.

5. Rowe RCR, Sheskey PJS, Cook W. Handbook Pharmaceutical Excipients,Sixth Edition. 2009;1064.

6. WHO. Trace elements in human nutrition and health World Health Organization. World Heal Organ. 1996;

7. Fordyce FM. Selenium deficiency and toxicity in the environment. In: Essentials 
of Medical Geology: Revised Edition. 2013.

8. Mutakin, Rivai IF, Setiawan A, Abdulah R, Kobayashi K, Yamazaki C, et al. A study of the association between selenium and cardiovascular disease in Lampung, Indonesia. Southeast Asian J Trop Med Public Health. 2016;

9. RISKESDAS. Riset Kesehatan Dasar; Badan Penelitian dan Pengembangan Kesehatan Kementerian Kesehatan RI Tahun2010. Lap Nas 2010. 2013;

10. WHO. Cardiovascular diseases (CVDs) fact sheets. Who. 2016.

11. Watkinson JH. Fluorometric Determination of Selenium in Biological Material with 2, 3-Diaminonaphthalene. Anal Chem. 1966;

12. Veiga N, Rivero-Huguet M, Huertas R. An improved spectrofluorometric determination of selenium in biological materials after microwave digestion. At Spectrosc. 2008;

13. Choi Y, Kim J, Lee HS, Kim C il, Hwang IK, Park HK, et al. Selenium content in representative Korean foods. J Food
Compos Anal. 2009;

14. Sirichakwal PP, Puwastien P, Polngam J, Kongkachuichai R. Selenium content of Thai foods. J Food Compos Anal. 2005;

15. Hamilton SJ. Review of selenium toxicity in the aquatic food chain. Science of the Total Environment. 2004.

16. Raymond C Rowe PJS and MEQ. Handbook of pharmaceutical excipient sixth edition. Revue des Nouvelles Technologies de 1'Information. 2009.

17. Voigt. Buku Pelajaran Teknologi Farmasi. Univ Gajah Mada Press. 1995;

18. Wise DL. Handbook of Pharmaceutical Controlled Release Technology. Handbook of Pharmaceutical Controlled Release Technology. 2000.

19. Lachman. Pharmaceutical Dosage Forms

- Tablets. Pharmaceutical Dosage Forms - Tablets. 2008.

20. Chairunnisa, Gozali D. Pengaruh Eksepien Penyalut Terhadap Stabilitas Obat. Farmaka. 2018; 